\title{
Political Economy of Aging in Latin America and the Caribbean: Economic (In)Security of Older Persons in the Twenty-First Century
}

\author{
Aida Diaz-Tendero Bollain \\ Research Center on Latin America and the Caribbean, National Autonomous University of Mexico, Mexico City, Mexico \\ Email: aidadi18@prodigy.net.mx
}

How to cite this paper: Diaz-Tendero, A. (2017) Political Economy of Aging in Latin America and the Caribbean: Economic (In)Security of Older Persons in the TwentyFirst Century. Open Journal of Social Sciences, 5, 83-100.

https://doi.org/10.4236/jss.2017.58007

Received: June 9, 2017

Accepted: August 4, 2017

Published: August 7, 2017

Copyright $\odot 2017$ by author and Scientific Research Publishing Inc. This work is licensed under the Creative Commons Attribution International License (CC BY 4.0).

http://creativecommons.org/licenses/by/4.0/

(c) (i) Open Access

\begin{abstract}
Objective: To apply the Political Economy of Aging approach to the study of the economic (in)security of the elderly in Latin America and the Caribbean. This approach studies the role of the State in the reproduction, attenuation or accentuation of inequities that affect the elderly population. Methods: Political economy indicators were applied such as a type of welfare regime, articulation of social policy based on assistance and social security, coverage, contributory and non-contributory pension systems to a sample of twenty countries of the region (Argentina, Bolivia, Brazil, Chile, Colombia, Costa Rica, Cuba, Dominican Republic, Ecuador, El Salvador, Guatemala, Haiti, Honduras, Mexico, Nicaragua, Panama, Paraguay, Peru, Uruguay and Venezuela). Results: The region presents a great heterogeneity in the type of State and welfare regime and its consequent effect on the economic security of the elderly. However, lack of protection exercised by the contributory systems predominates, which causes the need for non-contributory systems.
\end{abstract}

\section{Keywords}

Aging, Pensions, Latin America, Caribbean, Stratification, Pension Reform, Social Security, State

\section{Introduction}

The Political Economy of Aging is one of the aspects of major relevance in current Gerontology [1] linking Gerontology to Sociology-specifically to the social stratification theories in relation to class, gender, race/ethnic group-, as well as to State theories. Following, it will be applied to the question of economic security, or insecurity, provided by the State to citizens as they reach old age. 
In order to have a full view of the economic security of the older persons, it is necessary to complement the perspective of the Political Economy of Aging, which studies the structure at macro level, with middle and micro dimensions which influence the socioeconomic status of the older person. The Mexican and Latin American Schools have been very prolific in classifying the types of transfers according to their source, the form, formal/informal, direction, amongst other taxonomic criteria [2]. However, this text is concerned with the condition of the older person as a receiver of economic transfers, and not of all but of those emanating from the State, the so called formal transfers or pensions, derived from contributions carried out to social security systems during productive age.

\section{The Political Economy of Aging}

Some of its premises are the following: the core of gerontological investigation swings from the individual's capacity to adapt to old age to the social processes which determine distribution of resources [3]; the resources of older persons, and even the process of aging itself, are influenced by the position of the older person in the social structure, economic and social factors [4]; socioeconomic institutions bear influence on individuals throughout the life cycle and in old age [5]; and public policies relating to income, health, long term care and social services reflect and accentuate the "vital opportunities"-Weberian concept that refers to the "feasible group of options found by persons when they decide what to do [6]" in relation to the social placement of the individual within the structures of class and status [7].

The State organizes relations of class, gender and race/ethnic group by means of the Welfare State or other forms of social State whose policies are the result of social struggles (between the State, capital resources and work) and the dominant relations of power of a certain historic moment generated by the contradictions of capital and the crisis they create [8].

A State will be more social when "it recognises the right of its least favoured citizens to act, according to the law, against an unequal State of which the State itself is a part [9]". Experience indicates that in order to measure the social dimensions of the State it is necessary to quantify up to what point income is redistributed, equal opportunities are guaranteed and social rights are extended to the entire population, all this being carried out through social policies. These act principally by means of social security and social assistance. The preponderance and extent of subsidiarity of social security and social assistance will vary according to the State's Social Model. The main point of Social Security is that it is an attained right. The differentiating factor between Social Security and Social Assistance being that people contribute to a joint fund. Contributing grants the attained right to receive, a deference which separates Social Assistance programmes in which the benefits are not considered due rights. A second distinctive characteristic is that persons share the risks during the life cycle [5].

The type of Social State, the type of Welfare State [10] or type of Welfare re- 
gime (the latter concept being used for Latin American States) configures the status of the citizenship of individuals. The greater universality of a welfare regime, the greater the status of citizenship of individuals of a society and less is the weight of the dimensions of stratification such as class, gender and race/ethnic group in the generation of inequities.

Essentially, the Political Economy of Aging has been pioneer in responding to the question of what the role of the State is in the case of the elderly in general, and particularly in relation to their socioeconomic situation [8].

\subsection{The Economic Status of Older Persons Derived from Class}

From a neoweberian point of view in relation to class, as one of the dimensions that influences status, the Political Economy of Aging emphasizes the role played by the social class prior to retirement in determining the situation in old age, as well as the role continued to be performed in relation to the class of the older people who continue in the work force [4]. In general terms, this perspective concurs in that the individual experience of aging and the nature of age group relations vary immensely according to social class so that it is necessary to analyse both class and age [11].

The social class prior to retirement is determinant in relation to the situation to be lived in old age [4]. The higher income quintiles-class concept has been applied to the Elderly [12] [13] have the opportunity of saving during their life, which enables them to have resources upon arriving at old age, greater access to middle or high paying formal employment which enables them to contribute during more years and in greater amounts resulting in higher pensions. On the other hand, the lower income quintiles endure greater informal employment and consequently, in many cases, the minimum number of contributory years in order to be entitled to a pension- "pensioners without a pension [14]"-, is not reached, and in the event that it is, the amount is, on occasions, insufficient. Consequently, older persons in the lower income quintiles are underrepresented or simply excluded from social security. Certain Latin American and European scholars consider Social Security as the main umbrella and the parts are social insurance and social assistance. In other academic sectors, the Social State is the main umbrella and social security and social assistance are the parts. The latter is followed in this text [15].

\subsection{The Economic Status of Older Persons Derived from Gender}

Gender generates inequalities in old age in four different ways, as pointed out by Carroll L. Estes [8]: firstly, the pensions and social benefits are linked to remunerated work which, in itself is gender biased per se, secondly, non-remunerated reproductive work, mainly carried out by women is not recognized as work and, consequently, does not generate any rights to social benefits in old age; thirdly, the family status is conceptualized as permanent instead of temporary, whilst a growing number of women who enter the stage of old age do so in a certain civil 
status (married, single, divorced, widowed) which changes during the years of transition from old age to very old age; fourthly, and following from the previous three aspects, the older woman is to a greater extent than the older man excluded from social security to a greater extent.

With respect to the first point, access to work is conditioned by gender in various ways. On the one hand, women have more difficulty in acquiring high level jobs due to the so called "glass ceiling [16]"-denounced by the liberal line of feminism [17] - , as well as full time formal employment, due to the demands placed on her by home care, child care and/or caring for the elderly. Similarly, very often they receive a lower salary than men for the same job. Women concentrate on lower level jobs, part time jobs and, very often, informal jobs. Remunerated work carried out by older women has similar results: work in the informal sector, low remuneration and part time [18].

The second point emerges from the concept that the value of work relegates care and other forms of "productive" activity to second place. The line of welfare feminism [17] strives for material recognition of non-remunerated contributions carried out mainly by women, for example, the right to retribution in exchange for the care of dependent family members.

The third point has to do with certain presumptions on the expected life cycle, which give way to greater or better social benefits in old age for the sectors of the population who fulfil this model, and penalize those who don't. The main idea is that the principal receiver of social benefits is a working man of the second sector who fulfils the role of sole provider of family income, in the company of a woman dedicated to the home, who has left work once she married in order to dedicate her time to the family, firstly to bringing up children and later to caring for the elderly. The ideal life model is that of continued work as of leaving school up until retirement. However, the real beneficiaries of true fulfilment of this model are the men providers, as the woman who becomes a widow-and has followed this model-generally receives a lower pension (as second or dependent beneficiary) than the one received by the man (principal beneficiary). With respect to the women who are not in this "traditional" model and whose numbers are increasing (divorced, single, separated), their situation is even less favourable [19] [20] and considerably increases their probability of living a precarious economic situation in their old age [21].

The fourth way, in which the situation of the older woman differs, is in her greater dependence to State assistance. The fact that women live longer than men, means that they rely on State benefits or services, in terms of health and income, for a longer period of time. In this sense, it must be mentioned that women make up the greater part of the older population, a phenomenon that Angela O'Rand and the National Academy on Aging referred to in 1994 as "the feminization of aging" and which takes place in every country of the world [22].

It is important to emphasize that gender is added to class in the generation and multiplication of inequities and, it is for this reason, that these two aspects should be jointly studied. 


\subsection{The Economic Status of Older Persons Derived from Race/Ethnic Group}

Two aspects must be examined before addressing this subject. Firstly, and with the aim of not making mistakes in generalizations, the degree of ethnic/cultural and racial differences of the countries must be measured, in the case that such differences exist. Secondly, the aspect [23] that refers to the investigation on aging of the minorities is focussed mainly on its shortfalls and pathologies, whilst their resources and cultural strengths are overseen, for example, the role played by family and community support systems in Hispanic communities in the United States, as well as levels of religious involvement in the improvement of health, and other aspects of aging such as the approach of networks and transfers, as mentioned in the introduction.

Having clarified these points, it must be seen that older persons belonging to these minority groups are over represented in lower income groups.

Race/ethnic group-in multiracial and/or multiethnic societies-influences the socioeconomic situation of the older person, for similar reasons-in some aspects-as in the first point mentioned above on the aspect of gender, that is, the hard fact that the social benefits or pensions received in old age are conditioned by paid work carried out during the productive age. The latter is determined by the racial discrimination present in work opportunities throughout the life cycle. Similarly, in relation to race/ethnic group, the fourth point mentioned above on the focus on gender must be considered in the following way: the economic and social cumulative disadvantage which goes building up throughout the life cycle results in a greater exclusion from social security for the older persons belonging to minority groups [24] [25]. The underlying processes of cumulative disadvantage throughout the life cycle are not only the result of historic patterns of racial discrimination but also of the institutionalization of these patterns within the State in the form of institutional racism. According to the concept of intergenerational risk transmission, Gosta Esping-Andersen [10] would affirm that this is determined by racial or ethnic origin. This means that the dimensions of class, gender and race/ ethnic group should be studied in conjunction due to the fact that the resulting inequities of these dimensions maximize each other, resulting in a multiplied effect [14].

\section{Older Persons from a Multidimensional Perspective}

It is important to establish the need of jointly studying in a multidimensional fashion, the variables of age, class, gender and race/ethnic group. The result is not the sum of these together, sometimes it is exponential and often produces experiences and consequences with qualitative and quantitative differences [14].

The economic status of older persons is composed-at least-by the following dimensions: class, gender, race/ethnic group and status of citizenship. The latter is determined by the type of Social State, Welfare State or, in the case of the countries of Latin America and the Caribbean, the Welfare Regime. In this sense, the status of citizenship is barely one component which attenuates to a 
greater or lesser extent, the impact of the other components.

\section{Application of the Political Economy of Aging Theory to the Latin American and Caribbean Region}

In the tentative "application" of the Political Economy of Aging Theory to the case of Latin America and the Caribbean region with respect to the inequities of the pension systems for older persons according to class, gender and race/ethnic group, it is necessary to incorporate two new aspects that have not been present in the original formulation of the approach: type of locality and corporatism.

Type of locality (rural/urban) bears considerable influence in the possibilities of a citizen to have access to permanent formal employment and, consequently, to the social benefits and services in old age. The low proportion of rural workers who are right holders in relation to urban right holders is a generalized phenomenon in the countries of the region.

Corporatism is a dimension which refers to the special relationship between the State and certain citizens, or said more correctly, between the State and state corporations integrated by certain citizens. This is an aspect in which the State reproduces and maximizes inequities.

\subsection{Class status in the Region}

The region is characterized by great inequalities in the social security systems in relation to class so that the citizens who are amongst the lower income quintiles are practically excluded (Figure 1).

An outright lack of coverage can be seen (below 8 per cent) in the lower quintiles in the great majority of countries with the exception of Argentina, Brazil and Uruguay, which are the countries with greater lower quintiles coverage. In this sense, Chile represents an intermediate case and covers approximately 38 per cent of older persons in the first quintile, followed by Costa Rica and Venezuela.

\subsection{Gender Status in the Region}

The gender perspective was ignored to a greater or lesser extent by social security systems, depending on the country. Similarly, it did not take into account the generations whose productive years developed prior to the time when social benefits became obligatory, so that these continued to be excluded [26]. The pension is provided in relation to remunerated work carried out by the holder in the formal sector and/or remunerated work carried out in the formal sector by the spouse, as well as other pensions for other family relations or in the case of disability. Thus, from the perspective of receiving a pension as an entitled holder, the gender inequities initiate from the sexual division of work, which results in the stratification of the socioeconomic situation in old age. The role performed by women in social reproduction limits their opportunities of formal remunerated employment and of obtaining formation within the formal education system [27]. When they do acquire remunerated work, they normally hold low paying and low valued jobs that result in gender inequities in old age [28]. 


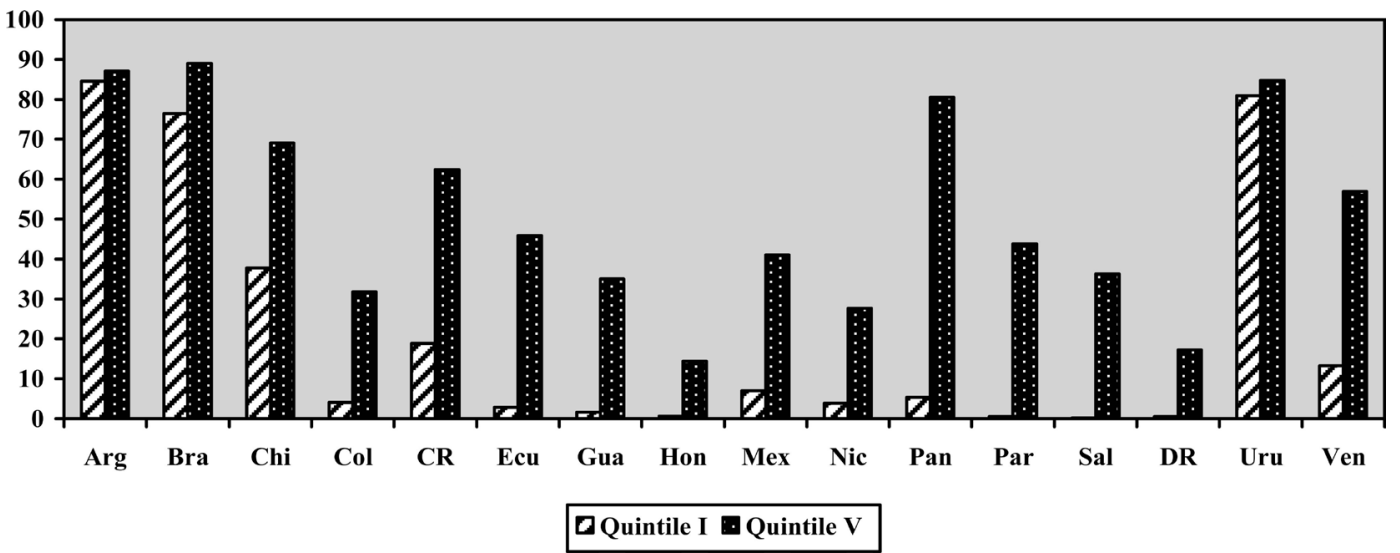

Figure $1^{1}$. Rate of coverage of social security systems according to the quintile of income (Q1 versus QV) in sixteen countries of the region. The data are from different years depending on the country: Argentina (2010), Brasil (2009), Chile (2009), Colombia (2009), Costa Rica (2008), Ecuador (2009), Guatemala (2006), Honduras (2009), México (2010), Nicaragua (2005), Panamá (2009), Paraguay (2009), El Salvador (2009), República Dominicana (2009), Uruguay (2010), Venezuela (2006). ( ${ }^{1}$ Figure compilation based on Rofman, R. and Oliveri, M. L. (2012), La cobertura de los sistemas previsionales en América Latina: conceptos e indicadores, Serie de documentos de trabajo sobre políticas sociales, núm. 7, Banco Mundial, Buenos Aires).

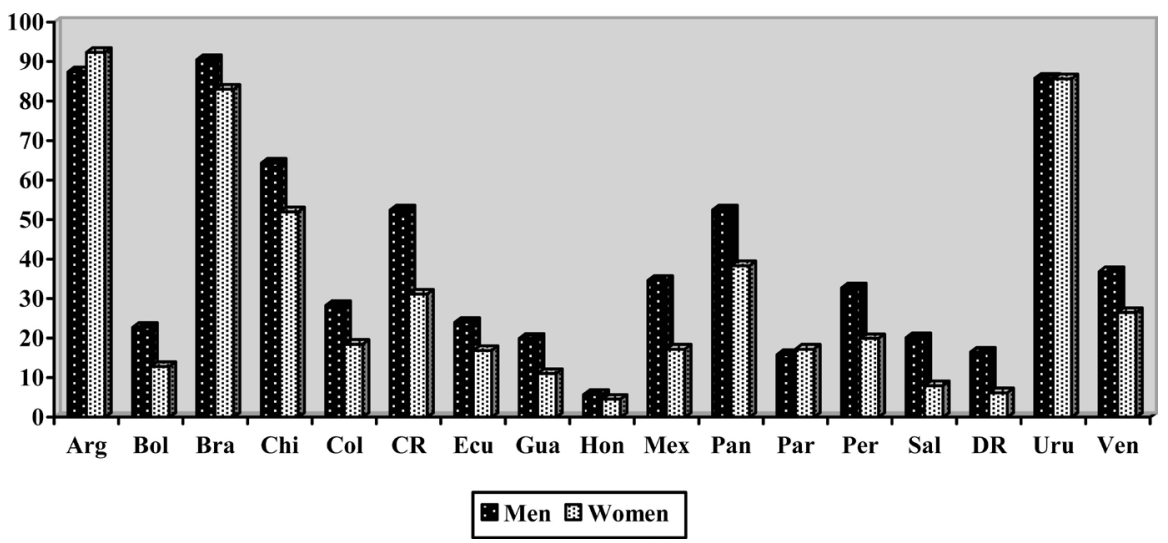

Figure $2^{1}$. Rate of coverage of social security systems according to sex, in seventeen countries of the region. The data are from different years depending on the country: Argentina (2010), Bolivia (2007), Brasil (2009), Chile (2009), Colombia (2009), Costa Rica (2008), Ecuador (2009), Guatemala (2006), Honduras (2009), México (2010), Panamá (2009), Paraguay (2009), Perú (2010), República Dominicana (2009), El Salvador (2009), Uruguay (2010), Venezuela (2006). ( ${ }^{1}$ Figure compilation based on Rofman, R. and Oliveri, M. L. (2012) La cobertura de los sistemas previsionales en América Latina: conceptos e indicadores, Serie de documentos de trabajo sobre políticas sociales, núm. 7, Banco Mundial, Buenos Aires).

This lesser participation in the job market contrasts with their greater participation in the informal sector (Figure 2).

The greatest gender inequity exists in El Salvador and The Dominican Republic where male coverage is in a ratio of 3 to 1 with that of women; followed by Mexico where male coverage is twice that of women. In the case of Argentina, older women enjoy greater coverage than older men and both are high. 


\subsection{Race/Ethnic Group Status Associated to Type of Locality Status in the Region}

Social security institutions of the countries of the region supported the processes of industrialization and urbanization - by means of coverage for the salaried urban formal worker-and marginalized rural development-through lack of coverage of the rural workers.

In general terms, in the majority of the countries of Latin America the pension systems are mainly concentrated in urban areas [29].

In countries with low social security coverage, protection is mainly concentrated in urban areas. The pension systems exclude workers in the informal sector as well as self-employed workers, tradesmen and agricultural workers [30].

It is advisable also to consider the race/ethnic group dimension as, in this case, there is often a double condition of indigenous or Afro descendant and rural element. The indigenous population as well as the Afro descendants concentrate in areas with low urban development, in other words, very rural areas (However, the indigenous population is progressively increasing in urban areas) [31].

It could be deducted that the inequity derived from the dimension of type of locality is summed to the dimension of race/ethnic group as it is no coincidence that the areas inhabited by the indigenous and Afro descendant populations are the most unprotected and register the greater marginalization.

Some of the dimensions of exclusion are: legal exclusion, since they are not taken into account by legal dispositions; economic exclusion: they do not contribute to a fund; exclusion by stigma: "they are peasants"; and social exclusion: "there is no custom" [32].

The greater the ethnic heterogeneity, the less is the coverage [33] as shown in the majority of countries of Latin America and the Caribbean.

In Guillermo Perry's words:

"All seems to indicate that in Latin America the more heterogeneous societies have tolerated [have propitiated] greater levels of social exclusion. Recent studies point out, in fact, that the racial or ethnic differences are amongst the most significant factors of social exclusion, understood as unequal access to a series of services and opportunities guaranteed by the rights to education, health, employment, political participation and civil rights ([33], p. 333; [34], p. 10)".

There are no studies giving evidence of a different rate of coverage with respect to the creole minority (Figure 3 ).

The rural/urban dimension shows even greater inequities than the gender dimension. Bolivia, Colombia, Ecuador, Guatemala, Honduras, Mexico, Nicaragua, Paraguay, Peru, El Salvador and The Dominican Republic show a ratio of at least 1 to 3 . Brazil seems to have been the most successful case, having reached greater coverage in the rural sector even over the urban sector. 


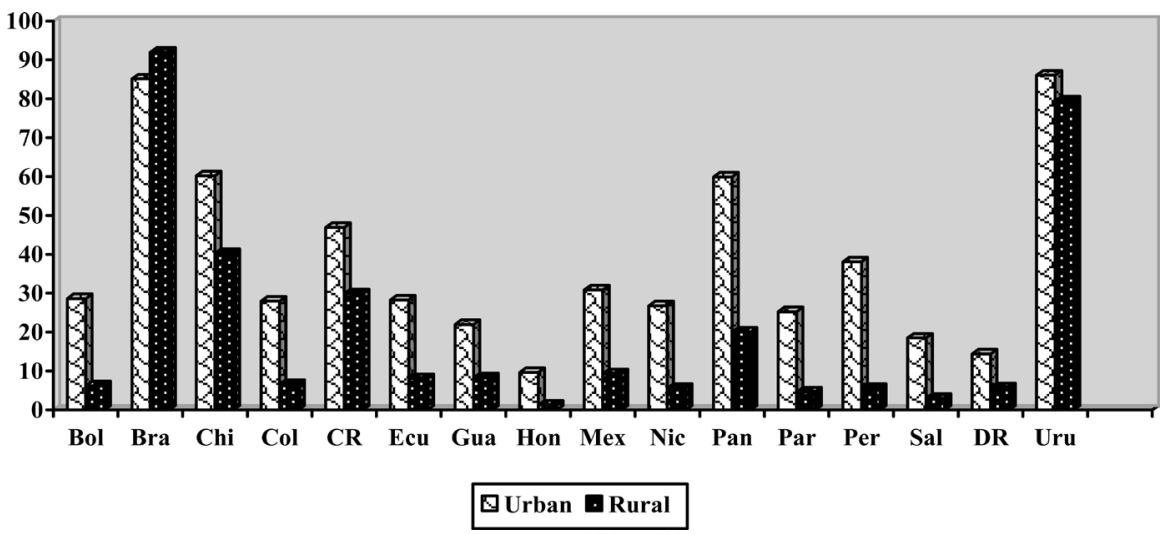

Figure $3^{1}$. Rate of coverage of social security systems according to the type of locality dimension (rural versus urban) in sixteen countries of the region. The data are from different years depending on the country: Argentina has no data for the rural population in any year and therefore is not included in the graph, Bolivia (2007), Brasil (2009), Chile (2009), Colombia (2009), Costa Rica (2008), Ecuador (2009), Guatemala (2006), Honduras (2009), México (2010), Nicaragua (2005), Panamá (2009), Paraguay (2009), Perú (2010), El Salvador (2009), Dominican Republic (2009), Uruguay (2010). ( ${ }^{1}$ Figure compilation based on Rofman, R. and Oliveri, M. L. (2012) La cobertura de los sistemas previsionales en América Latina: conceptos e indicadores, Serie de documentos de trabajo sobre políticas sociales, núm. 7, Banco Mundial, Buenos Aires).

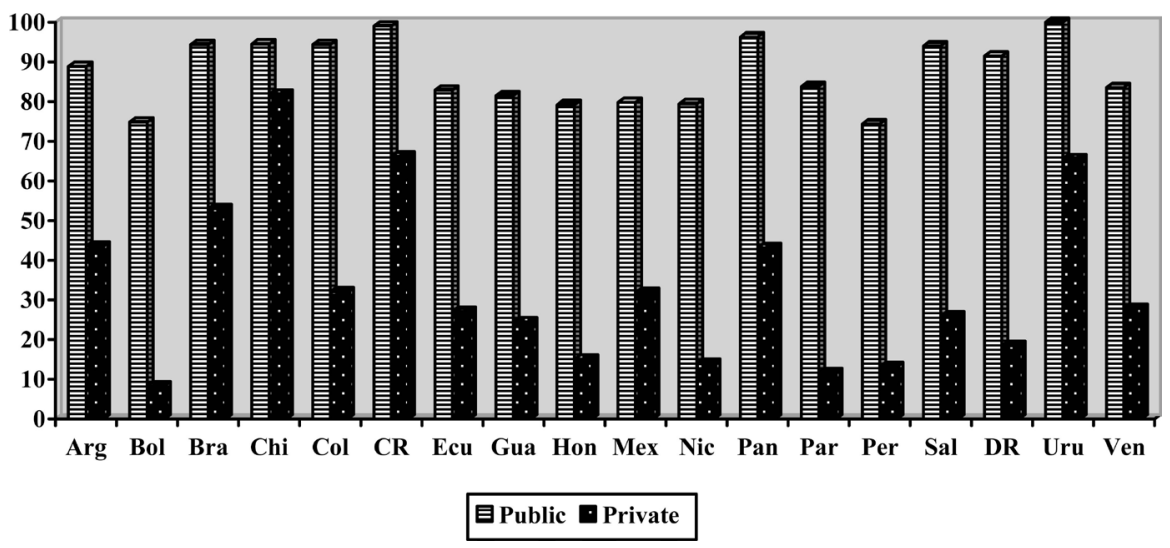

Figure $4^{1}$. Rate of coverage of social security systems according to the corporatism (public/private) dimension in eighteen countries of the region. The data are from different years depending on the country: Argentina (2010), Bolivia (2007), Brasil (2009), Chile (2009), Colombia (2009), Costa Rica (2008), Ecuador (2009), Guatemala (2006), Honduras (2009), México (2010), Nicaragua (2005), Panamá (2009), Paraguay (2009), Perú (2010), El Salvador (2009), Dominican Republic (2009), Uruguay (2010) y Venezuela (2006). ( ${ }^{1}$ Figure compilation based on Rofman, R. and Oliveri, M. L. (2012) La cobertura de los sistemas previsionales en América Latina: conceptos e indicadores, Serie de documentos de trabajo sobre políticas sociales, núm. 7, Banco Mundial, Buenos Aires).

\subsection{Status Derived from Belonging to a State Corporation in the Region}

Although it is not present in the formulation of the original approach, corporatism is an essential State-citizen relation in the sample countries (Figure 4).

The principal observation to be made in relation to graph No. 4 is the very 
high coverage enjoyed by older persons who have worked in the public sector, which surpasses 80 per cent in all countries. The countries with the highest coverage in the private sector are Chile, Costa Rica and Uruguay.

\subsection{Social State/Welfare Regime Status in the Region}

Economic status of older persons is conditioned by the aforementioned dimensions as well as by the type of Welfare Regime. The Latin American Welfare Regimes, which were established during the period between the twenties and sixties of the past century have been reformed modifying the type of welfare regime, although coverage has not increased as a result of these reforms. On the other hand, it is necessary to take into account the existence or not of non-contributory pensions and the extent of these as they constitute a palliative to the lack of coverage of the contributory systems (Table 1 ).

In so far as the Latin American welfare regimes are concerned, Carlos Barba [35] proposes the following classification of regimes in the decade of the seventies of the past century: universalistic, dual and exclusive. Argentina, Chile, Costa Rica, Cuba and Uruguay belong to the universalistic welfare regime.

"They are comparatively characterized as they have States that are very active in terms of social aspects, having promoted a gradual and universalizing expansion of social rights and they articulated social protection systems with the formal labour market and unions ([33], pp. 338-339)".

For their part, the dual regimes (Brazil, Colombia, Mexico and Venezuela) and the exclusive ones (Bolivia, Ecuador, Guatemala, Haiti, Honduras, Nicaragua, Paraguay, Peru, El Salvador and the Dominican Republic) are noted for:

"A decline of one and two steps respectively, in the indicators considered [referring to life expectancy at birth, infant mortality, illiteracy and other indexes] (...), as well as in levels of social spending, social security coverage, education and preventive health services (...). And also for a gradual increase in ethno cultural heterogeneity, the regressive nature of social protection systems and the degree of informality in labour markets ([33], p. 340)".

Juliana Martínez-Franzoni [36] divides the welfare regimes of Latin America and the Caribbean of the middle of the first decade of this century into state-protectionist, state-productivist, familiaristic and highly familiaristic. The state-productivist is characterized by public policies focussed on improving the conditions of the labour force in order to participate in the labour market (cases of Argentina and Chile). The public policies of the state-protectionist model emphasize social protection according to the contributions associated to occupations, particularly in formal sectors of the economy (Brazil, Costa Rica, Mexico, Panama and Uruguay). The familiaristic (Colombia, Ecuador, Guatemala, Peru, El Salvador and Venezuela) and highly familiaristic models (Bolivia, Honduras, Nicaragua and Paraguay) do not constitute different types rather they are the same type with different levels. The State has very limited capacity and the in- 
Table $1^{1}$. Welfare Regimes in twenty countries of the region according to different taxonomic criteria.

\begin{tabular}{|c|c|c|c|c|c|c|}
\hline & \multirow{2}{*}{$\begin{array}{l}\text { Barba } \\
(2003)\end{array}$} & \multirow{2}{*}{$\begin{array}{l}\text { Martínez-Franzoni } \\
\qquad(2007)\end{array}$} & \multirow{2}{*}{$\begin{array}{l}\text { Mesa-Lago } \\
\text { (1994) }\end{array}$} & \multicolumn{2}{|c|}{ (Mesa-Lago, 2009) } & \multirow{2}{*}{ Non Contributory Pensions } \\
\hline & & & & Groups & Reforms and model & \\
\hline Period & $\begin{array}{l}\text { Up until the decade } \\
\text { of } 1970\end{array}$ & $\begin{array}{l}\text { Data } \\
2004-2006\end{array}$ & $\begin{array}{l}\text { Decade of } 1980 \text { and beginning of } \\
\text { the } 1990 \text { decade }\end{array}$ & $\begin{array}{l}\text { Data } \\
2004-2006\end{array}$ & Decade of 1990 & Established prior to 2010 \\
\hline Arg & Universalistic & State-productive & Pioneer high & 1 & $\begin{array}{l}\text { Mixed (returned to the } \\
\text { public system 2008) }\end{array}$ & $\begin{array}{l}\text { Available for the rural and urban } \\
\text { sectors }\end{array}$ \\
\hline Bol & Exclusive & Highly familiaristic & Intermediate & 3 & $\begin{array}{l}\text { Substitute but studying } \\
\text { reform }\end{array}$ & $\begin{array}{l}\text { Renta Dignidad not exclusively } \\
\text { rural }\end{array}$ \\
\hline Bra & Dual & State-protectionist & Pioneer-high & 1 & $\begin{array}{l}\text { Public } \\
\text { (parametric reforms) }\end{array}$ & Rural prevision system since $1988^{2}$ \\
\hline Chi & Universalistic & State-productivist & $\begin{array}{l}\text { Pioneer } \\
\text { High }\end{array}$ & 1 & $\begin{array}{l}\text { Substitute (1981) } \\
\text { re-reform in } 2008\end{array}$ & $\begin{array}{l}\text { Available for rural and urban } \\
\text { sectors }\end{array}$ \\
\hline CR & Universalistic & State-protectionist & $\begin{array}{l}\text { Is an exception: late }(60-70) \text { but } \\
\text { high coverage, emerges united } \\
\text { and almost universal }\end{array}$ & 1 & Mixed & $\begin{array}{l}\text { Available } \\
\text { rural and urban coverage }\end{array}$ \\
\hline $\mathrm{Cu}$ & Universalistic & & $\begin{array}{l}\text { Is an exception: late }(60-70) \text { but } \\
\text { high coverage statist and } \\
\text { universal }\end{array}$ & 1 & $\begin{array}{l}\text { Public, with parametric } \\
\text { reforms }\end{array}$ & \\
\hline Ecu & Exclusive & Familiaristic & Intermediate & 3 & Public & Since 2003 by means test for $65+$ \\
\hline Gua & Exclusive & Familiaristic & Late $(60-70)$-low & 3 & Public & Since 2005 by means test for $65+$ \\
\hline Hai & Exclusive & & Late $(60-70)$-low & 3 & Public & \\
\hline Hon & Exclusive & Highly familiaristic & Late $(60-70)$-low coverage & 3 & Public & \\
\hline Mex & Dual & State-protectionist & Intermediate & 2 & $\begin{array}{l}\text { Substitute } \\
(1997 \text { y } 2007)\end{array}$ & $\begin{array}{l}\text { Since } 2003 \text { universal } 68+\text { in Mexico } \\
\text { City; since } 2007 \text { universal } 70+\text { in } \\
\text { certain locations of the country }\end{array}$ \\
\hline Nic & Exclusive & Highly familiaristic & Late $(60-70)$-low coverage & 3 & Public & \\
\hline Pan & & State-protectionist & $\begin{array}{l}\text { Intermediate ( } 40.50) \text { - } \\
\text { intermediate coverage }\end{array}$ & 1 & Mixed (since 2008) & $\begin{array}{l}\text { Since } 2009 \text {, for } 70+\text { that have no } \\
\text { other pension }\end{array}$ \\
\hline Par & Exclusive & Highly familiaristic & Late-low & 3 & Public & $\begin{array}{l}\text { Since } 2010 \text { by means test } 65+\text { in } \\
\text { certain locations }\end{array}$ \\
\hline Per & Exclusive & Familiaristic & Intermediate & 3 & Parallel & $\begin{array}{l}\text { Since } 2011 \text { by means test } 65+\text { and } \\
\text { in certain locations }\end{array}$ \\
\hline Sal & Exclusive & Familiaristic & Late $(60-70)$-low coverage & 3 & Substitute & $\begin{array}{l}\text { Since } 2003 \text {, for } 70+\text {, in the rural } \\
\text { sector and by means test }\end{array}$ \\
\hline $\mathrm{DR}$ & Exclusive & Familiaristic & Late $(60-70)$-low coverage & 3 & $\begin{array}{l}\text { Substitute but allows } \\
\text { return to the public }\end{array}$ & \\
\hline Uru & Universalistic & State-protectionist & Pioneer-high & 1 & Mixed & $\begin{array}{l}\text { Available for both rural and urban } \\
\text { sectors }\end{array}$ \\
\hline Ven & Dual & Familiaristic & Intermediate & 2 & Public & \\
\hline
\end{tabular}

${ }^{1}$ Self elaborated table based on: Barba, C. (2003) El nuevo paradigma de bienestar residual y deslocalizado. Reforma de los regímenes de bienestar en la $O E C D$, América Latina y México (phdthesis), University of Guadalajara, Guadalajara (Mexico); United Nations Population Fund (UNFPA)/HelpAge International HAI (2012)Aging in theTwenty-First Century: A Celebration and A Challenge, UNFPA/HAI, New York; Martínez-Franzoni, J. (2007)Regímenes de bienestar en América Latina,Carolina Foundation, Madrid (Spain); Mesa-Lago, C. (1994) Changing Social Security in Latin America: Towardsalleviatingthecosts of economicreform, LyenneRienner Publisher, London; Mesa-Lago, C. (2009)Efectos de la crisis global sobre la seguridad social de salud y pensiones en América Latina y el Caribe y recomendaciones de políticas,EconomicCommissionforLatin America and theCaribbean,Santiago de Chile; Rofman, R. and Oliveri, M. L. (2012) La cobertura de los sistemas previsionales en América Latina: conceptos e indicadores, Serie de documentos de trabajo sobre políticas sociales, núm. 7, Banco Mundial, Buenos Aires; Rossel, C. (2012) Protección social y pobreza rural en América Latina, Food and AgricultureOrganization of theUnited Nations (FAO), Santiago de Chile. ${ }^{2}$ Brazil established universal coverage for elderly women rural workers, reduced the age of retirement by five years in relation to those of urban workers, a minimum retirement was established for rural workers equivalent to the minimum salary. 
ternational organizations play a greater role. Similarly, there are a great proportion of families with scarce resources that contribute with unpaid community work for their own services in areas where it could be expected that these should be the responsibility of local or central governments, such as the construction of schools or even its administration.

Carmelo Mesa-Lago [37] classification of 1994 is the first of all regional taxonomies. The categories went according to the chronological time in which they were established, identifying correlation between coverage of the pension systems during the eighties and the beginning of the nineties, on the one hand, and the chronological time in which these systems were established, on the other. The pioneer-high group (to which Latin American countries such as Uruguay, Argentina, Chile-its Social Security System was established in 1926 [38] and Brazil belong) was the first in establishing social security systems in the region during the twenties and thirties, and the systems belonging to this group were the ones that reached greater development and coverage, (approximately between 73 and 87 per cent). The intermediate group - including Panama, Mexico, Peru, Colombia, Bolivia, Ecuador and Vene-zuela - implemented their programmes mainly in the decade of the forties and fifties, and their coverage was also intermediate (oscillating between 13 and 67 per cent). The late-low group including the Dominican Republic, Guatemala, El Salvador, Nicaragua, Honduras and Haiti was the last in introducing their programmes, and, in the same fashion, these are the countries which display the lower coverage (approximately between 9 and 27 per cent). In principle, there exists a direct relationship between the age and coverage of the systems. Notwithstanding, the system in Costa Rica which belongs to the group of late implementation, having been installed in the sixties and seventies, is a unified system from its beginnings and has reached almost universal coverage; the Cuban system, established in the same period a state oriented social security scheme of universal coverage [33] [37].

The new classification of the same author published in 2009 takes into account multiple indicators of the first mid-decade of this century in terms of health and economic security in old age. According to the figures displayed by the different countries in the various indicators, three conglomerates may be identified. The regimes offering the greater coverage belong to the first group (Argentina, Brazil, Chile, Costa Rica, Cuba, Panama, Uruguay); the second group comprises those with intermediate figures (Colombia, Mexico and Venezuela); and the third group includes those regimes offering the lower coverage (Bolivia, Ecuador, Guatemala, Haiti, Honduras, Nicaragua, Paraguay, Peru, El Salvador and The Dominican Republic).

It is very clear from the light of Figures 1-4 and of Table 1, that the fulfilment of the hypothesis that: the greater universality of the welfare regimes (Barbauniversalistic types, state-protectionist and state-productivist of Martínez-Franzoni, pioneer-high of Mesa-Lago and the first group by the same author) the lesser incidence of stratification dimensions such as class, gender, race/ethnic group and/or type of locality with respect to the economic security of older persons. If 
one compares the values shown by the countries of the region in the sample, in relation to these dimensions, one finds that the greater coverage of the lower income quintiles is found in Argentina and Uruguay; of women, in Argentina, Uruguay and Chile; of rural localities in Brazil and Uruguay; and of the private sector, in Chile.

If one compares which countries show most similar values in coverage of the quintiles of greater and lesser incomes, of men and women, of rural and urban localities, of the public and private sector, it is evident that Argentina stands out for the least inequity both in terms of class and gender dimensions; Chile in relation to class, gender, type of locality and corporatism; and Uruguay in relation to class, gender and type of locality. Contrary to these countries whose welfare regimes are classified as universalistic, Honduras and Paraguay display very similar values both for men and women but in the sense of the lower coverage of the two.

\subsubsection{Reforms of the Pension Systems in the Region}

In most developed countries pension systems privatization has been justified by the increase in life expectancy, the rapid change in demographic structures, and the lack of prevision and financial crisis. In addition to these arguments, in some countries of Latin America and the Caribbean the following have been put forth: the deviation of resources to other benefits of Social Security, the use of resources for ends foreign to the system, the inadequate administration, corruption and concession of high benefits to special groups who contributed in a minimum fashion or not at all [39].

The introduction of the neoliberal method in terms of pensions has not been homogenous in the region. Additionally, the main deficiency of the contributive systems: the lack of coverage has not been corrected by the reforms. The countries that, according to all taxonomic criteria, are at the first level of coverage have not implemented substitute systems. Defined benefits system (pay as you go) is substituted for the defined contributions system [40] (except for Chile, although this country carried out a reform in 2008 of the privatization reform of 1981): Argentina, Panama and Uruguay have a mixed system-the mixed system reforms the public system and integrates it with that of individual capitalization. The former pays a basic pension whilst the private one pays a complementary pension [41], and Brazil and Cuba maintain the public system although they have introduced parametric reforms. The countries of the second level have behaved in a dissimilar fashion, Colombia having a parallel model, Venezuela a public one and Mexico implemented substitute reforms (1997 and 2007) in true Chilean style. Lastly, the countries with lower coverage and with more exclusive welfare regimes are characterized by their heterogeneity: Ecuador, Guatemala, Haiti, Honduras, Nicaragua and Paraguay remain in the public system; Bolivia, El Salvador and the Dominican Republic privatized; and Peru maintains a parallel system.

The wave of privatization arrives when many developing countries have not 
yet reached a minimum status of social citizenship, this translated into the language of the economic security of older persons means that great proportions of this age group still remain excluded.

\subsubsection{Non-Contributory Pensions}

An indicator which completes the picture referring to the role played by the State in the economic security of older persons is the existence or not of noncontributory pensions, which are relatively generalized in the region. These pensions are not derived from contributions to social security by work performed in the formal sector, and consequently compensate the inequities related to the dimensions of the stratification which hinder access to formal work and, in this way, to the system of contributory pensions.

Amongst their favourable points, they guarantee almost total coverage for the population with no resources [42] [43] [44] and who suffer all the inequities resulting from the dimensions of class, gender, race/ethnic group and type of locality.

\section{Conclusions}

In general terms, the welfare regimes of the region accentuate inequality and marginalize broad sectors of the population of older persons (prior to and following from the reforms), proving the basic premise of the Political Economy of Aging, according to which older persons are not always poorer than other age groups of the population-as other mechanisms of the private spheres intervene, such as savings, transfers from their descendants, amongst others-but in so far as transfers from the State are concerned, of actions and systems exercised and implemented respectively by the State, these reproduce and even accentuate the inequities derived from the stratification dimensions.

The region is characterized by the heterogeneity of the welfare regimes and the reach of the privatizing reforms, and by the relative homogeneity in the implementation of different types of non-contributory pensions of varying degrees of coverage. Exclusion is more acute according to the dimensions of class, gender and type of locality. In this sense, the worst scenario in terms of economic security provided by the State is expected by lower class older women living in rural areas and/or belonging to an ethnic minority. The best scenario can be expected by urban older men who worked as civil servant or were employed by a state corporation.

The greater universality of the welfare regime, the less inequality are generated by the stratification dimensions; the more exclusive the regime is, the greater the incidence of the mentioned dimensions in the generation of inequities is.

The tentative application of the Political Economy of Aging in the region shows, primarily, potential for the study of older persons due to the characteristics of these States and societies: firstly, the high degree of stratification and the deficit of citizenship present in various countries. Secondly, the role played by 
the exclusive welfare regimes (prior to and after the reforms) in the generation and perpetuation of said stratification deserves the study of the dynamics and established mechanisms that provoke, intensify and prolong the inequities. Thirdly, the explicit use made by this approach of the dimensions of class, gender, race/ethnic group is essential for Latin America and the Caribbean, adding those of type of locality and corporatism. Finally, the economic status of the older person derived from formal contributive transfers proceeding from the State is conditioned according to class, gender, race/ethnic group, type of locality, corporatism and the type of welfare regime.

A more in depth analysis of each country remains pending taking into account the different categories in which they lie according to each author, as well as taxonomic criteria particularly for those countries that are not always at the same level according to different authors. Thus, countries such as Brazil and Panama merit a more in depth study. On the other hand, it is particularly necessary to elaborate to a greater extent on cases of countries such as Costa Rica and Cuba that, in spite of late establishment of their social security systems, achieved broad coverage. In this same line, Panama is a relevant case in that it is the only country of the group that created their systems in the forties and fifties (group conformed by Bolivia, Colombia, Ecuador, Mexico, Peru and Venezuela) that has achieved insertion into the first group according to the classification of Mesa-Lago (2009) according to data of the first decade of the twenty first century.

There would also remain pending a more thorough analysis of the conceptual differentiation, as well as in terms of public policy of social assistance and social security. These concepts perceive social assistance as a less desirable branch of greater stigma for the population benefiting from it as opposed to social security, which is considered as a justiciable right to be demanded from the State, not subject to electoral changes. However, in the region the importance of social assistance is so significant in terms of coverage, geographic extension and decades of performance that it would perhaps be worth questioning this outright separation. Particularly in the case of the economic security of older persons, noncontributory pensions constitute a social assistance policy that could be situated on the borderline between social assistance and social security.

Due to the fact that the reforms have not progressed in the direction of greater coverage, it would be pertinent to propose non-contributory pensions-either means tested or universal-as the most viable way of achieving the necessary broadening of coverage and attenuation of the inequities resulting from the dimensions of stratification (class, gender, race/ethnic group and type of locality) that the social security contributory systems have generated in a considerable proportion of the countries of the region.

\section{References}

[1] Bengtson, V.L., et al. (2009) Handbook of Theories of Aging. Springer, New York. 
[2] Diaz-Tendero, A. (2016) La Teoria de la Economia Politica del Envejecimiento. Un nuevo enfoque para la gerontologia social en Mexico. El Colegio de la Frontera Norte, Tijuana.

[3] Bengtson, V.L., et al. (1997) Theory, Explanation, and a Third Generation of Theoretical Development in Social Gerontology. Journal of Gerontology: Series B, Psychological Sciences and Social Sciences, 52, S72-S88. https://doi.org/10.1093/geronb/52B.2.S72

[4] Minkler, M. and Estes, C.L. (1999) Critical Gerontology: Perspectives from Political and Moral Economy. Baywood, New York.

[5] Quadagno, J. and Reid, J. (1999) The Political Economy Perspective in Aging. In: Vern, L., Bengtson, V.L. and Warner Schaie, W., Eds., Handbook of Theories of Aging, Springer, New York.

[6] Raya, E. (2002) Políticas sociales y ciudadanía: La condición social de las personas demandantes de prestaciones sociales en la Comunidad Autónoma del País Vasco, Central Publication Service of the Basque Government, Vitoria-Gasteiz, 37.

[7] Estes, C.L. (1999) Critical Gerontology and the New Political Economy of Aging. In: Minkler, M. and Estes, C.L., Eds., Critical Gerontology: Perspectives from Political and Moral Economy, Baywood, Amityville.

[8] Estes, C.L., et al. (2001) Social Policy and Aging: A Critical Perspective. Sage Publications, Thousand Oaks.

[9] Touraine, A. (1994) Quées la democracia. Temas de Hoy, Madrid, 89.

[10] Esping-Andersen, G. (1990) The Three Worlds of Welfare Capitalism. Polity Press, Cambridge.

[11] Dowd, J.J. (1999) Stratification among the Aged. Brooks/Cole, Monterey, 21-22.

[12] Ehrenreich, B. and Ehrenreich, J. (1979) The Professional Managerial Class. In: Walker, P., Ed., Between Labor and Capital, South End Press, Boston.

[13] Wright, E.O. (1995) Análisis de Clase. In: Carabaña, J., Ed., Desigualdad y Clases sociales, Visor/Fundación Argentaria, Madrid.

[14] Dressel, P., et al. (1999) Gender, Race, Class, and Aging: Advances and Opportunities. In: Minkler, M. and Estes, C.L., Eds., Critical Gerontology: Perspectives from Political and Moral Economy, Baywood, New York.

[15] Marasco, N.I. and Fernández, M.A. (2013) La Solidaridad en la Seguridad Social. Hacia una ciudadanía Social. Centro Interamericano de Estudios de Seguridad Social (CIESS), Mexico City.

[16] Hymowitz, C. and Schelhardt, T.D. (1986) The Glass-Ceiling: Why Women Can't Seem to Break the Invisible Barrier that Blocks Them from Top Jobs. The Wall Street Journal, 57, D1, D4-D5.

[17] Ritzer, G. (1993) Teoría Sociológica Contemporánea. Mac Graw Hill, Madrid.

[18] Holstein, M. (1999) Women and Productive Aging: Troubling Implications. In: Minkler, M. and Estes, C.L., Eds., Critical Gerontology: Perspectives from Political and Moral Economy, Baywood, New York.

[19] Pascall, G. (1986) Social Policy: A Feminist Analysis. Tavistock, New York.

[20] Harrington Meyer, M. (1990) Family Status and Poverty among Older Women: The Gendered Distribution of Retirement Income in the US. Social Problems, 37, 551563.

[21] Whitehouse, E. (2000) How Poor Are the Old? A Survey of Evidence from 44 Countries. In: World Bank, Ed., World Bank Social Protection Discussion Paper Se- 
ries, Social Protection Unit, Washington DC, 17.

[22] United Nations (2002) Population Aging 2002. Population Division/Department of Economic and Social Affairs, New York.

[23] Binstock, R.H. and George, L.K. (2001) Handbook of Aging and the Social Sciences. Academic Press, San Diego.

[24] Henretta, J.C. and Campbell, R.T. (1976) Status Attainment and Status Maintenance: A Study of Stratification in Old Age. American Sociological Review, 41, $981-$ 992. https://doi.org/10.2307/2094798

[25] O’Rand, A.M. (1996) The Cumulative Stratification of the Life Course. In: Binstock, R.H. and George, L.K., Eds., Handbook of Aging and the Social Sciences, Academic Press, San Diego.

[26] Montes Oca, V. (2001) Desigualdad structural entre la Población anciana en México. Factores que han condicionado el Apoyo institucional entre la Población con 60 Años y Más en México. Estudios Demográficos y Urbanos, 48, 585-613.

[27] Stone, R.I. (1989) The Feminization of Poverty among the Elderly. Women's Studies Quarterly, 17, 20-34.

[28] Huenchuan, S. (2004) Pobreza y Redes de Apoyo en la Vejez. Acercamiento desdelas diferencias de Género. Congress of the Asociación Latinoamericana de Población (ALAP), Caxambu.

[29] Gomes Conceicao, M.C. (2005) Envejecimiento, Pobreza y Familia. International Congress on Avances en Gerontología, Instituto Nacional para las Personas Adultas Mayores, Inapam.

[30] Guzmán, J.M. (2002) Envejecimiento y Desarrollo en América Latina y el Caribe. Population and Development Series, Latin American and Caribbean Demographic Centre, Santiago de Chile.

[31] Economic Commission for Latin America and the Caribbean-ECLAC (2014) Los Pueblos Indígenas en América Latina. Avances en el Ultimo Decenio y Retos pendientes para la Garantía de sus derechos. Economic Commission for Latin America and the Caribbean, Santiago de Chile.

[32] Fajardo, G. (2006) Experiencias Comparadas en Los Sistemas de Pensiones para Campesinos. Revista CIESS, 12, 39-53.

[33] Barba, C. (2009) Los Regímenes de Bienestar latinoamericanos y la Reforma Social. In: Barba, C., et al., Eds., Másallá de la Pobreza. Regímenes de Bienestar en Europa, Asia y América, University of Guadalajara/El Colegio de la Frontera Norte, México.

[34] Perry, G. (2001) Prologue to Workshop Proceedings on Poverty and Social Exclusion in Latin America. In: Gacitía, E., et al., Eds., Social Exclusion and Poverty Reduction in Latina America and the Caribbean, Latin American School of Social Sciences (FLACSO)/World Bank (WB), Washington DC, 10.

[35] Barba, C. (2003) El Nuevo Paradigma de Bienestar Residual y Deslocalizado. Reforma de Los Regímenes de Bienestar en la OECD, América Latina y México. Ph.D. Thesis, University of Guadalajara, Mexico.

[36] Martínez-Franzoni, J. (2007) Regímenes de Bienestar en América Latina. Carolina Foundation, Madrid.

[37] Mesa-Lago, C. (1994) Changing Social Security in Latin America: Towards Alleviating the Costs of Economic Reform. Lyenne Rienner Publisher, London.

[38] United Nations (2007) World Economic and Social Survey 2007. Development in an Aging World. Department of Economic and Social Affairs, New York.

[39] Ham, R. (2005) Necesidades apremiantes, Riesgos económicos y Obstáculos sociales 
en la Recomposición de Las pensiones de Retiro en América Latina. Proceedings of UN Expert Group Meeting on Social and Economic Implications of Changing Population Age Structures, Mexico City, 31st August-2nd September 2005.

[40] Walker, A. and Deacon, B. (2003) Economic Globalization and Policies on Aging. Journal of Societal and Social Policy, 2, 1-18.

[41] Mesa-Lago, C. (2009) Efectos de la Crisis Global Sobre la Seguridad Social de Salud y Pensiones en América Latina y el Caribe y Recomendaciones de Políticas. Economic Commission for Latin America and the Caribbean, Santiago de Chile.

[42] Bertranou, F. (2004) Reformas a Los Sistemas de Jubilaciones y Pensiones en América Latina: Paradigmas y Temas emergentes. Revista Seguridad Social, 250, 11 22.

[43] Bertranou, F. (2005) Restricciones, Problemas y Dilemas de la Protección Social en América Latina: Enfrentando Los Desafíos Del Envejecimiento y la Seguridad de Los Ingresos. Bienestar y Política Social, 1, 5-58.

[44] Scott, J. (2008) Hacia la Universalidad de la Seguridad Social en México. In: Ham, R., et al., Eds., Evaluación y Tendencias de Los Sistemas de Pensiones en México, El Colegio de la Frontera Norte/Instituto de Investigaciones Económicas-UNAM/ Miguel Ángel Porrúa, Mexico City.

\section{Submit or recommend next manuscript to SCIRP and we will provide best service for you:}

Accepting pre-submission inquiries through Email, Facebook, LinkedIn, Twitter, etc. A wide selection of journals (inclusive of 9 subjects, more than 200 journals) Providing 24-hour high-quality service User-friendly online submission system Fair and swift peer-review system Efficient typesetting and proofreading procedure Display of the result of downloads and visits, as well as the number of cited articles Maximum dissemination of your research work

Submit your manuscript at: http://papersubmission.scirp.org/

Or contact jss@scirp.org 